\title{
Critical Risk Factors of Construction Industry of Pakistan for Improving Project Outcome
}

\author{
WAQAS FARID*, NADEEM ISHAQ KURESHI*, SUQRAT BABAR**, AND SHAHID MAHMOOD*** \\ RECEIVED ON 03.09.2018, ACCEPTED ON 19.02.2019
}

\begin{abstract}
The aim of this paper is to identify various risk factors faced by construction industry during execution phase of the project. Relevant published literature was studied for the identification of the risk factors and professionals from the local construction industry of Pakistan were asked to rank these risk factors as per their impact on the local projects. Qualitative risk analysis was conducted using the RII (Relative Importance Index) scores and risk scores were calculated. To improve the quality of construction key risk factors highly influencing the local construction industry of Pakistan were identified. Amongst these factors, Construction delays due to unforeseen impediments, payment delays from Client and unreasonable and inflexible decisions were the crest causes highly influencing the project outcome. The top ten risks faced at projects in Pakistan were listed, discussed and conclusions were drawn.
\end{abstract}

Key Words: Project Risk Management, Risk Management, Risk Factors, Risk Identification, Construction Management.

\section{INTRODUCTION}

$\mathrm{C}$ onstruction industry not only helps in improving the life style of a country by providing better infrastructure and other facilities but also plays a key responsibility in its development [1] and boosting its GDP (Gross Domestic Product) [2]. Construction projects are unique in nature and every project differs from the other in terms of complexity, design, location, stakeholders, size, etc. [3]. Construction industry is facing many problems [4]. Dynamic nature of projects [5] and their enhancing complications have highly stressed the construction industry due to involvement of extensive risk factors and these numerous risk factors if not properly identified and managed can even cause project failure
[6]. Construction risks directly hamper the progress of the project and highly influence the project objectives that include budget, schedule, scope, quality, safety, sustainability and stakeholder satisfaction [7]. Of all the negative effects these risk factors have on a construction project, cost and time overruns are the most common [8]. The probability of cost and time overruns in a construction project is far greater [9] and is ranked as the most severe problem in construction industry globally [10-11]. Taking in account all the risk factors construction industry is exposed to, project risk management has been identified as an essential tool to help improve the performance of the project [6]. Risk identification and its

Authors E-Mail: (waqas_muqeet@hotmail.com, nadeemkureshi@gmail.com, suqrat@gmail.com, cda_shahid@yahoo.com)

* Department of Engineering Management, Centre for Advanced Studies in Engineering, Islamabad, Pakistan.

** Department of Construction Engineering \& Management, National University of Science \& Technology, Islamabad, Pakistan.

*** Capital Development Authority, Islamabad, Pakistan.

This is an open access article published by Mehran University Research Journal of Engineering and Technology, Jamshoro under the CC by 4.0 International License. 
assessment itself is a critical task and if done properly can ensure the success of any construction project [12]. After identification and understanding of the risk factors responsible for affecting project objectives and causing overruns, stakeholders can prepare better plans and have contingency amount figured out and included in the cost estimates to ensure success of the project [13]. Project Managers can improve the quality of construction by planning the project with the knowledge of key risk factors in advance.

\section{LITERATURE REVIEW}

\subsection{Risk Management}

In a broader aspect risk can be defined as the probability of an occurrence during the project which can affect its goals and this effect is not necessarily always negative [14]. Risks can be both opportunity and threat but most of the times risks hamper the projects in a negative way therefore only negative side of risk is given significance [15]. Risk management is a key aspect of a good project management plan [16] and in any project the most difficult task is the risk identification and its prioritization [17]. Risk management is a process that starts at the project initiation and ends at project closure and constitutes of identification and evaluation of risk factors, their mitigation and control for success of project [18].

\subsection{Risk Identification, Analysis and Control}

Identification of risk factors is the foremost phase of project risk management as prospective risk factors are identified during this phase [19]. Perera et. al. [20] stressed upon effective management of necessary information and site related knowledge. According to Zavadskas et. al. [3] risks can be classified in three major heads i.e. external risks, internal risks and project risks. After the identification process of all possible risks, severity can be analyzed by their risk scores i.e. calculating their probability and impact. Risks having higher scores are highlighted and mitigation techniques are developed for monitoring and controlling purposes [21]. According to Han et. al. [22] risk control constitutes of five processes that are risk identification, analysis, evaluation, response and monitoring.

\subsection{Risk Management in Construction Industry}

The number of stakeholders in a construction project is relatively higher than other industries; these stakeholders include the government, government approval agencies, owners, investors, design consultants, supervision consultants, contractors, suppliers, sub-contractors, local manufacturers and the general public being the end user. Due to involvement of different bodies and some uncertain/unforeseen conditions and constraints construction projects are always prone to risks [23]. Lately, the research work done on risk management in construction field has significantly grown as it is now naturally believed that the projects inherit substantial amount of risks because of the numerous stakeholders involved [24]. In broader aspect, the two major stake holders having the maximum risk exposure are the contractors and the clients [25] and both the parties have their own traditional methods to cover up for these risk factors [26]. Despite of all the research being done on risk management in construction industry, only limited methods are practiced amongst which risk identification is the most commonly used method which is followed by qualitative analysis and quantitative analysis techniques [27]. Quantitative techniques are not very common as they require high quality of data and detailed information which at times is not available or easily understandable in construction projects [28] therefore, no substantial work is done after the identification of potential risk factors [29]. 
Moreover, in recent years the traditional risk management technique has been integrated with other industry project monitoring tools like earned value analysis to address its limitations and provide project managers with better and realistic results [30]. For instance, Narbaev and De Marco [31] proposed a framework model using s-curves for better cost forecasting using contingency management and De Marco et. al. [32] worked on forecasting nonlinear cost estimates at completion adjusted with risk contingency.

The risk factors can badly hamper the project objectives and cause overruns of both time and cost [3]. At times these risk factors can even result in complete project failure [33]. Taking in account the severity of the risks construction projects are exposed to project risk management is a vital tool and can facilitate and improve decision making [34].

\section{RESEARCH METHODOLOGY}

To identify the risk factors faced in the construction industry, relevant literature was studied. Literature regarding the most common risk factors affecting all type of construction projects were studied and listed down. As identified from the literature the three major types of risks were explored i.e. internal, external and project related risks. As per El-Sayegh [23] project related risks fall under internal category of risk therefore the same approach was adopted in this research where the identified risks were divided in two major heads internal and external risks. A broad literature review was done and more than 300 published articles were studied in detail. Risk factors related to the construction industry were identified and listed down for further use. For initial shortlisting of these identified risk factors, frequency analysis was done. Risk factors which had frequency greater than four (rate of appearance in studied published literature) were shortlisted. To further strengthen and to incorporate opinion from construction industry experts in Pakistan, a pilot study was done by getting the identified risk factors reviewed/evaluated by 11 industry experts. During the pilot study the shortlisted risk factors were further categorized into relevant groups i.e. Internal and External Risk Factors. After validation of risk factors from pilot survey, a questionnaire based survey form was developed to rank the identified risks. The survey was divided in two sections where section 1 was regarding the personal details of the respondent whereas in the second section the respondents were asked to give the probability and impact of the risk factors on a five point Lickert scale of very low (1) to very high (5). Following the methodology from El-Sayegh\& Mansour [35] the results obtained from the survey were used to find the RII of both the probability and impact using the Equation (1).

$$
\mathrm{RII}=\frac{\sum \mathrm{W}}{\mathrm{A} \times \mathrm{N}}(0 \leq \mathrm{RII} \leq 1)
$$

Where $\mathrm{W}$ is the weightage ranging from very low (1) to very high (5), A is the maximum weightage in the survey question i.e. very high (5) in the conducted survey for this study and $\mathrm{N}$ denotes the number of respondents.

The responses were collected and reliability of data was checked using Cronbach Alpha test. To find the risk score of the identified risk factors the RII scores of probability and impact were multiplied and their risk score was obtained. The risk score was used to rank the identified risk factors and the top ten factors affecting the project objectives were identified and discussed.

\section{RESULTS,ANALYSISAND DISCUSSION}

After detailed study of literature, 283 risk factors relating to the construction industry were identified. After conduction frequency analysis, 66 risk factors were shortlisted for further use in this research. 22 of the

Mehran University Research Journal of Engineering \& Technology, Volume 39, No. 1, January, 2020 [p-ISSN: 0254-7821, e-ISSN: 2413-7219] 
shortlisted risk factors were under external risk factor group whereas the remaining 44 pertained to internal risk factor group. To rank these risk factors a questionnaire based survey was conducted. A total 125 questionnaires were distributed to industrial professionals all over Pakistan; only 52 responded. $76 \%$ of the respondents were from Industry and the rest were working in academia. 33 respondents were having experience more than 15 years and the remaining 19 were having experience between 10 to 15 years. Majority of the respondents $(76 \%)$ were working with contractor followed by consultant (14\%) and client $(10 \%)$. To check the reliability of the data Chronbach Alpha test was applied and the alpha value obtained was 0.861 making the data highly reliable.

The results obtained from the survey were used to find the RII values of the probability and impact of the risk factors. The results were used to find the risk values and are shown in Table 1.

TABLE 1. RISK FACTORS CLASSIFIED WITH THEIR SCORES AFTER SURVEY

\begin{tabular}{|c|c|c|c|c|c|c|}
\hline \multirow{2}{*}{ No. } & \multirow{2}{*}{ Risk Factors } & \multicolumn{2}{|c|}{ Probability } & \multicolumn{2}{|c|}{ Impact } & \multirow{2}{*}{ Risk core } \\
\hline & & Score & RII & Score & RII & \\
\hline \multicolumn{7}{|c|}{ Experimental Risk Factors } \\
\hline \multicolumn{7}{|c|}{ Political Risks } \\
\hline 1. & Political instability & 134.4 & 0.52 & 162.4 & 0.62 & 0.32 \\
\hline 2. & Poor economic policies & 190.4 & 0.73 & 218.4 & 0.84 & 0.62 \\
\hline 3. & Poor trade policy & 117.6 & 0.45 & 124.88 & 0.48 & 0.22 \\
\hline 4. & International political instability & 117.6 & 0.45 & 168.56 & 0.65 & 0.29 \\
\hline 5. & Bureaucratic problems & 194.67 & 0.75 & 140 & 0.54 & 0.4 \\
\hline \multicolumn{7}{|c|}{ Economic Risks } \\
\hline 6. & Operational risk & 72.8 & 0.28 & 95.2 & 0.37 & 0.1 \\
\hline 7. & Insurance risks & 128.8 & 0.5 & 174.72 & 0.67 & 0.33 \\
\hline 8. & Liquidity risk & 89.6 & 0.34 & 84 & 0.32 & 0.11 \\
\hline 9. & Taxation risks & 145.6 & 0.56 & 117.6 & 0.45 & 0.25 \\
\hline 10. & Diversification risks & 95.2 & 0.37 & 112.06 & 0.43 & 0.16 \\
\hline 11. & Foreign exchange/Currency fluctuation risk & 134.4 & 0.52 & 179.2 & 0.69 & 0.36 \\
\hline 12. & Integrative management risks & 89.6 & 0.34 & 119 & 0.46 & 0.16 \\
\hline 13. & Natural catastrophes/Force majeure & 173.6 & 0.67 & 190.4 & 0.73 & 0.49 \\
\hline 14. & Inflation & 195 & 0.75 & 181 & 0.7 & 0.52 \\
\hline \multicolumn{7}{|c|}{ Social Risks } \\
\hline 15. & Changes to laws/regulatory changes & 173.6 & 0.67 & 117.94 & 0.45 & 0.3 \\
\hline 16. & New deal structures & 95.2 & 0.37 & 84 & 0.32 & 0.12 \\
\hline 17. & National cultural differences & 117.6 & 0.45 & 114.8 & 0.44 & 0.2 \\
\hline 18. & Cultural communication & 114.8 & 0.44 & 104.72 & 0.4 & 0.18 \\
\hline 19. & Information risks & 106.4 & 0.41 & 109.54 & 0.42 & 0.17 \\
\hline 20. & Pollution caused by construction & 105 & 0.4 & 93 & 0.36 & 0.14 \\
\hline 21. & Lack of experience of client & 156.8 & 0.6 & 190.4 & 0.73 & 0.44 \\
\hline \multicolumn{7}{|c|}{ Weather Risks } \\
\hline 22. & Abnormal weather and climatic conditions & 215 & 0.83 & 219 & 0.84 & 0.7 \\
\hline \multicolumn{7}{|c|}{ Internal Risk Factors } \\
\hline \multicolumn{7}{|c|}{ Resource Risks } \\
\hline 1. & Lack of availability of required resources & 156.8 & 0.6 & 230.83 & 0.89 & 0.54 \\
\hline 2. & Material unavailability & 131.04 & 0.5 & 232.78 & 0.9 & 0.45 \\
\hline 3. & Slow delivery of equipment & 123.76 & 0.48 & 179.93 & 0.69 & 0.33 \\
\hline 4. & Labor Shortage & 138.32 & 0.53 & 204.57 & 0.79 & 0.42 \\
\hline 5. & Late deliveries of construction materials & 190.4 & 0.73 & 212.8 & 0.82 & 0.6 \\
\hline
\end{tabular}

Mehran University Research Journal of Engineering \& Technology, Volume 39, No. 1, January, 2020 [p-ISSN: 0254-7821, e-ISSN: 2413-7219] 
Critical Risk Factors of Construction Industry of Pakistan for Improving Project Outcome

\begin{tabular}{|c|c|c|c|c|c|c|}
\hline \multirow{2}{*}{ No. } & \multirow{2}{*}{ Risk Factors } & \multicolumn{2}{|c|}{ Probability } & \multicolumn{2}{|c|}{ Impact } & \multirow{2}{*}{ Risk core } \\
\hline & & Score & RII & Score & RII & \\
\hline \multicolumn{7}{|c|}{ Project Member/Stakeholders Related Risks } \\
\hline 6. & Lack of experience of contractor & 174.16 & 0.67 & 220.76 & 0.85 & 0.57 \\
\hline 7. & Inappropriate intervention by client & 164.3 & 0.63 & 185.92 & 0.72 & 0.45 \\
\hline 8. & Client Satisfaction & 180.88 & 0.7 & 219.69 & 0.84 & 0.59 \\
\hline 9. & Slow decision making by stakeholders & 166.88 & 0.64 & 214.59 & 0.83 & 0.53 \\
\hline 10. & $\begin{array}{l}\text { Technical excellence/ incompetence of professionals and } \\
\text { managers assigned to the project }\end{array}$ & 190.96 & 0.73 & 205.97 & 0.79 & 0.58 \\
\hline 11. & Unreasonable and inordinate decisions & 216.83 & 0.83 & 255.36 & 0.98 & 0.82 \\
\hline \multicolumn{7}{|c|}{ Technological Risks } \\
\hline 12. & Technological Advanced & 182 & 0.7 & 222.99 & 0.86 & 0.6 \\
\hline \multicolumn{7}{|c|}{ Construction Site Risks } \\
\hline 13. & Project land Acquisition & 166.88 & 0.64 & 255.36 & 0.98 & 0.63 \\
\hline 14. & Errors during construction & 155.68 & 0.6 & 241.92 & 0.93 & 0.56 \\
\hline 15. & Site conditions and Unknown Geological Conditions of site & 179.76 & 0.69 & 241.92 & 0.93 & 0.64 \\
\hline 16. & Contractors' Site management Skills & 121.41 & 0.47 & 216.72 & 0.83 & 0.39 \\
\hline \multicolumn{7}{|c|}{ Time/Duration Risk } \\
\hline 17. & Poor project planning due to insufficient project information & 201.6 & 0.78 & 230.89 & 0.89 & 0.69 \\
\hline 18. & Unsuitable construction program planning & 180.32 & 0.69 & 216.83 & 0.83 & 0.58 \\
\hline 19. & Slow equipment productivity & 145.6 & 0.56 & 179.76 & 0.69 & 0.39 \\
\hline 20. & Poor labor Productivity (value added per head) & 186.48 & 0.72 & 173.6 & 0.67 & 0.48 \\
\hline 21. & Construction delays due to unexpected obstructions & 260.4 & 1 & 237.1 & 0.91 & 0.91 \\
\hline \multicolumn{7}{|c|}{ Construction Risks } \\
\hline 22. & Design variations & 174.72 & 0.67 & 236.51 & 0.91 & 0.61 \\
\hline 23. & Incomplete design and poorly defined project objectives & 180.32 & 0.69 & 249.31 & 0.96 & 0.67 \\
\hline 24. & Complete change in design & 168.67 & 0.65 & 224.67 & 0.86 & 0.56 \\
\hline 25. & Size of project & 206.08 & 0.79 & 207.2 & 0.8 & 0.63 \\
\hline \multicolumn{7}{|c|}{ Work Quality Risks } \\
\hline 26. & Rework and losses due to poor planning and execution & 225.12 & 0.87 & 238.34 & 0.92 & 0.79 \\
\hline 27. & Poor Materials quality & 176.4 & 0.68 & 224.5 & 0.86 & 0.59 \\
\hline 28. & Poor quality systems & 169.12 & 0.65 & 210.56 & 0.81 & 0.53 \\
\hline 29. & Substandard quality of work & 201.6 & 0.78 & 216.83 & 0.83 & 0.65 \\
\hline \multicolumn{7}{|c|}{ Cost Risks } \\
\hline 30. & Financial management risk & 162.4 & 0.62 & 174.27 & 0.67 & 0.42 \\
\hline 31. & Contractor's credit risk & 112.11 & 0.43 & 137.2 & 0.53 & 0.23 \\
\hline 32. & $\begin{array}{c}\text { Uncertain fluctuation in market prices of construction } \\
\text { materials }\end{array}$ & 174.1 & 0.67 & 255.36 & 0.98 & 0.66 \\
\hline 33. & Estimating error & 146.16 & 0.56 & 243.04 & 0.93 & 0.53 \\
\hline 34. & $\begin{array}{c}\begin{array}{c}\text { Payment delays due to clients poor and uncertain financial } \\
\text { management }\end{array} \\
\end{array}$ & 235.76 & 0.91 & 248.08 & 0.95 & 0.87 \\
\hline \multicolumn{7}{|c|}{ Documents and Information Risks } \\
\hline 35 & $\begin{array}{c}\text { Lack of coordination/ poor communication between project } \\
\text { participants/stakeholders }\end{array}$ & 182.34 & 0.7 & 205.52 & 0.79 & 0.55 \\
\hline 36 & $\begin{array}{l}\text { Inadequate or insufficient site information (soil test and } \\
\text { survey report) }\end{array}$ & 117.6 & 0.45 & 236.88 & 0.91 & 0.41 \\
\hline \multicolumn{7}{|c|}{ Health and Safety Risks } \\
\hline 37 & Lack of Toolbox meetings & 168.56 & 0.65 & 204.51 & 0.79 & 0.51 \\
\hline 38 & Lack of Safety training & 181.44 & 0.7 & 180.76 & 0.7 & 0.49 \\
\hline 39 & Accident frequency ratio at site & 119.45 & 0.46 & 216.72 & 0.83 & 0.38 \\
\hline \multicolumn{7}{|c|}{ Other Risks } \\
\hline 40 & Conflicts and disputes and litigation between stakeholders & 195.44 & 0.75 & 249.2 & 0.96 & 0.72 \\
\hline 41 & Occurrence of dispute/ labor strikes & 108.3 & 0.42 & 241.92 & 0.93 & 0.39 \\
\hline 42 & Inadequate scope & 168.67 & 0.65 & 211.68 & 0.81 & 0.53 \\
\hline 43 & Bureaucratic Delay & 131.29 & 0.5 & 161.06 & 0.62 & 0.31 \\
\hline 44 & Uncoordinated variation in project deliverables & 217.84 & 0.84 & 240.24 & 0.92 & 0.77 \\
\hline
\end{tabular}

Mehran University Research Journal of Engineering \& Technology, Volume 39, No. 1, January, 2020 [p-ISSN: 0254-7821, e-ISSN: 2413-7219] 
As per the survey results the top ten risk factors that are highly critical in the construction industry of Pakistan were identified and are listed below as per their risks scores.

(i) Construction delays due to unexpected obstructions.

(ii) Payment delays due to client's poor and uncertain financial management.

(iii) Unreasonable and inordinate decisions.

(iv) Rework and losses due to poor planning and execution.

(v) Uncoordinated variation in project deliverables.

(vi) Conflicts, disputes and litigation between stakeholders.

(vii) Abnormal weather and climatic conditions.

(viii) Poor project planning due to insufficient project information.

(ix) Incomplete design and poorly defined project objectives.

(x) Uncertainty and fluctuation in market prices of construction materials.

As per the results obtained after the survey construction delays due to slow progress was ranked as the highest rated risk factor affecting the construction industry of Pakistan. These delays due to low productivity at site not only affect the project cost and time baselines but also highly influence project outcomes. Delays and overruns are common all around the world due to numerous reasons but are very significant and commonly observed in construction industry of Pakistan. These delays due to low productivity at site not only affect the project cost and time baselines but also highly influence project outcomes. Payment delays from client was ranked second highest after the risk ranking. Payment delays are very commonly observed in Pakistan in both public and private projects. Most of the projects in Pakistan at some stage suffer due to financial and funding problems which directly influence the project deliverables. The third highest ranked risk factor after survey results was incomplete approvals from relevant authorities. In Pakistan many projects are started prior to their complete approvals and proper documentation due to various reasons including political pressure. Such projects later on during the execution phase suffer due to missing documentation and approvals and face legal actions hampering the project objectives. Rework due to defects and poor construction quality was ranked as fourth highest risk factor and is very commonly observed in Pakistani construction industry. As quality of work is undermined at times to meet other objectives like cost and time limits producing inferior quality of construction which at times need rework and repairs. The rework and repair not only adds additional cost and time to the project baselines but also is not as per the quality standards thus hampering the project objectives. The fifth highest ranked risk factor in construction industry of Pakistan as per the survey results was issuance of uncoordinated change orders. Change orders are part of the construction projects but excessive and uncoordinated change orders can always affect the primary objectives of the projects and somehow have negative effect. Conflicts and disputes are ranked sixth most critical risk factor in construction industry of Pakistan. Claims are normally a result of the dispute and conflict took place between the stakeholders due to numerous reasons that can be both contractual and non-contractual. In Pakistan such disputes are commonly observed on mega public projects due to non-obligation of contractual obligations by both parties. Abnormal weather and climatic conditions was ranked as the seventh highest risk factor in construction

Mehran University Research Journal of Engineering \& Technology, Volume 39, No. 1, January, 2020 [p-ISSN: 0254-7821, e-ISSN: 2413-7219] 
industry of Pakistan. As the weather of Pakistan is very dynamic where most of the region in north is covered in snow half of the year whereas in the south the temperature and humidity makes it hard to work in the summers therefore making climate a major risk factor in construction industry of Pakistan. Moreover, heavy rain falls in the monsoon region and in the winters is also common in most parts of the country hampering the construction progress. Poor project planning was also ranked by respondents as a critical risk factor. At times, clients usually want their projects to be completed in unrealistic timelines due to various reasons that include political pressure and business activities. Poor project planning and unrealistic milestones are a major risk, stakeholders have to do extra efforts and embrace other risks that come alongside. Incomplete design approvals is a major risk factor in construction industry of Pakistan and is ranked $9^{\text {th }}$ highest by the respondents. As discussed above, due to political pressure or business strategies, construction projects are kick started despite on incomplete design documents which may even result in stoppage of work at times. Uncertain fluctuation in prices of construction materials was ranked as the tenth highest risk factor in construction industry of Pakistan. As Pakistani economy is weak and major fluctuation is commonly observed which results in price inflation and changes in prices of construction commodities especially bitumen, cement and steel which is a major chunk of construction projects therefore making price inflation as a critical risk factor in Pakistani industry.

\section{CONCLUSIONS}

Construction industry of Pakistan is full of uncertainties and this research has helped in ranking some key risks faced by majority of the projects being executed locally. The results indicate that delay in construction due to slow progress is the major risk with high probability and impact on projects in Pakistan. This risk factor highlights the fact that many of the projects in Pakistan lack proper planning and management which are the basic causes of delays in construction projects. Delay is a very critical type of risk because its effect is not only limited to project timelines and cash flow but it leads to poor quality of work and other complications like disputes.

This research also shows that in Pakistan, internal risk factors are much more dominant than external risk factors in Pakistani construction industry. Nine out of ten identified critical risk factors were from the internal group and only abnormal weather and climatic conditions was ranked in the top ten critical risk factor. Although political and economic condition of the country is not very stable but professionals are still of the view that internal risk factors affect much more as compared with external risk factors that include country's economy and political status.

Another interesting trend observed was that the ownership of the identified critical risk factors. Although the top critical risk factor i.e. delays is at contractor's end but the second and third highest ranked critical risk factors were pertaining to the Client i.e. financial and incomplete approvals. Similarly, rework is a risk related to the contractor but the other risks in the top ten list are not exclusive to the contractor but involve other stakeholders as well.

As in most of the projects in Pakistan, risks are contractually transferred to the contractor thus resulting in contingency amounts being earmarked or hidden in the project baseline cost. This practice can easily be avoided by contractually obligating stakeholders of their risks and this practice can easily help in more realistic baseline schedules and cost estimates of the project. This practice can indirectly not only lead to better quality of work at site but fewer disputes and claims. 
This research is limited to the qualitative risk analysis as quantitative analysis of all risk factors is a difficult task. The key purpose of this research was to identify and highlight key risk factors having major influence on the local construction industry to help Project Managers have beforehand knowledge of key risk factors of construction projects and decide regarding the response planning of these highlighted risk factors. Furthermore, it is up to the Project Manager to decide whether to do the quantitative analysis of the critical risk factors or the mitigation strategies to be adopted to avoid these risk factors.

\section{FUTURE WORK}

In the future research, it is suggested that RII scores for various construction types can be calculated to explore further avenues for improving project outcomes. However, it is further recommended that other countries may also apply this study as a reference document for their construction industry. Moreover, this study can be taken as a benchmark for country - comparative analysis.

\section{ACKNOWLEDGEMENT}

Authors thank Center for Advanced Studies in Engineering, Sir Syed University of Engineering \& Technology, Karachi, Pakistan, for their valuable guidance and support.

\section{REFERENCES}

Memon, N.A., Memon, F.A., and Khehro, S.H., "Prefabrication in Building Construction: A Perspective of Pakistan Construction Industry", Mehran University Research Journal of Engineering \& Technology, Volume 33, No. 3, pp. 346-351, Jamshoro, Pakistan, July, 2014.

[2] Abdul Rahman, I., Memon, A.H., Karim, A., and Tarmizi, A., "Significant Factors Causing Cost Overruns in Large Construction Projects in Malaysia", Journal of Applied Science, Volume 13, No. 2, pp. 286-293, 2013.
[3] Zavadskas, E.K., Turskis, Z., and Tamošaitiene, J., "Risk Assessment of Construction Projects", Journal of Civil Engineering and Management, Volume 16, No. 1, pp. 33-46, 2010.

[4] Memon, N.A., Abro, Q.M.M., and Memon, Z.A., "ISO in the Construction and Manufacturing Companies: A Case Study from the Construction Industry of Hyderabad and Karachi, Pakistan”, Mehran University Research Journal of Engineering \& Technology, Volume 30, No. 2, Jamshoro, Pakistan, April, 2011.

[5] Memon, A.H., Soomro, M.A., Memon, N.A., and Abassi, M.N., "Factors Causing Health and Safety Hazards in Construction Projects in Pakistan”, Mehran University Research Journal of Engineering \& Technology, Volume 36, No. 3, pp. 559-568, Jamshoro, Pakistan, July, 2017.

[6] Zeng, J., An, M., and Smith, N.J., "Application of a Fuzzy Based Decision Making Methodology to Construction Project Risk Assessment”, International Journal of Project Management, Volume 25, No. 6, pp. 589-600, 2007.

[7] Zou, P.X., Zhang, G., and Wang, J., "Understanding the Key Risks in Construction Projects in China", International Journal of Project Management, Volume 25, No. 6, pp. 601-614, 2007.

[8] Senouci, A., Ismail, A.A., and Eldin, N., "Time and Cost Overrun in Public Construction Projects in Qatar", Creative Construction Conference, Budapest, pp. 25-28, 2016.

[9] Emhjellen, M., Emhjellen, K., and Osmundsen, P., "Cost Estimation Overruns in the North Sea", Project Management Journal, Volume 34, No. 1, pp. 23-29, 2003.

[10] Cantarelli, C.C., "Cost Overruns in Dutch Transportation Infrastructure Projects", Delft University of Technology. Conference Presentation, pp. 19-20, 2009.

[11] Olawale, Y.A., and Sun, M., "Cost and Time Control of Construction Projects: Inhibiting Factors and Mitigating Measures in Practice", Construction Management and Economics, Volume 28, No. 5, pp. 509-526, 2010. 
[12] Barkley, B., "Project risk management", McGraw-Hill, New York, USA, 2004.

[13] Creedy, G.D., "Risk Factors Leading to Cost Overrun in the Delivery of Highway Construction Projects", P.D., Dissertation, Queensland University of Technology, 2006.

[14] Serpella, A.F., Ferrada, X., Howard, R., and Rubio, L., "Risk Management in Construction Projects: A Knowledge-Based Approach", Procedia-Social and Behavioral Sciences, Volume. 119, pp. 653-662, 2014.

[15] Hillson, D., "Dealing with Business Uncertainty", Unloaded from: http://www.risk-doctor.com/briefings, 2011 .

[16] Alali, B., and Pinto, A., "Project, Systems and Risk Management Processes Interactions". IEEE International Conference on Management of Engineering \& Technology, pp. 1377-1386, Portland, 2009.

[17] Anderson, S., "Risk Identification and Assessment", PMI Virtual Library, 2009.

[18] Lee, E., Park, Y., and Shin, J.G., "Large Engineering Project Risk Management Using a Bayesian Belief Network", Expert Systems with Applications, Volume 36, No. 3, pp. 5880-5887, 2009.

[19] Van Os, A., Van Berkel, F., De Gilder, D., Van Dyck, C., and Groenewegen, P., "Project Risk as Identity Threat: Explaining the Development and Consequences of Risk Discourse in an Infrastructure Project”, International Journal of Project Management, Volume 33, No. 4, pp. 877-888, 2015.

[20] Perera, B.A.K.S., Dhanasinghe, I., and Rameezdeen, R., "Risk Management in Road Construction: The Case of Sri Lanka", International Journal of Strategic Property Management, Volume 13, No. 2, pp. 87-102, 2009.

[21] Choi, H.H., Cho, H.N., and Seo, J.W., "Risk Assessment Methodology for Underground Construction Projects”, Journal of Construction Engineering and Management, Volume 130, No. 2, pp. 258-272, 2004.
[22] Han, S.H., Kim, D.Y., Kim, H., and Jang, W.S., “A WebBased Integrated System for International Project Risk Management", Automation in Construction, Volume 17, No. 3, pp. 342-356, 2008.

[23] El-Sayegh, S.M., "Risk Assessment and Allocation in the UAE Construction Industry", International Journal of Project Management, Volume 26, No. 4, pp. 431-438, 2008.

[24] Forbes, D., Smith, S., and Horner, M., “Tools for Selecting Appropriate Risk Management Techniques in the Built Environment", Construction Management and Economics, Volume 26, No. 11, pp. 1241-1250, 2008

[25] Bryde, D.J., and Volm, J.M., "Perceptions of Owners in German Construction Projects: Congruence with Project Risk Theory", Construction Management and Economics, Volume 27, No. 11, pp. 1059-1071, 2009.

[26] Baloi, D., and Price, A.D., "Modelling Global Risk Factors Affecting Construction Cost Performance”, International Journal of Project Management, Volume 21, No. 4, pp. 261-269, 2003.

[27] Lyons, T., and Skitmore, M., "Project Risk Management in the Queensland Engineering Construction Industry: A Survey", International Journal of Project Management, Volume 22, No. 1, pp. 51-61, 2004.

[28] Schieg, M., "Model for Integrated Project Management", Journal of Business Economics and Management, Volume 10, No. 2, pp. 149-160, 2009.

[29] Zayed, T., Amer, M., and Pan, J., "Assessing Risk and Uncertainty Inherent in Chinese Highway Projects Using AHP”, International Journal of Project Management, Volume 26, No. 4, pp. 408-419, 2008.

[30] Babar, S., Thaheem, M.J. and Ayub, B., "Estimated Cost at Completion: Integrating Risk into Earned Value Management", Journal of Construction Engineering and Management, Volume 143, No.3, pp.04016104, 2016.

[31] Narbaev, T., and De Marco, A., "Earned Value and Cost Contingency Management: A Framework Model for Risk Adjusted Cost Forecasting", Journal of Modern Project Management, Volume 4, No. 3, pp. 12-19, 2017 
[32] De Marco, A., Rosso, M., and Narbaev, T., "Nonlinear Cost Estimates at Completion Adjusted with Risk Contingency”, Journal of Modern Project Management, Volume 4, No. 2, pp. 22-31, 2016.

[33] Renuka, S.M., Umarani, C., and Kamal, S., “A Review on Critical Risk Factors in the Life Cycle of Construction Projects", Journal of Civil Engineering, Volume 4, pp. 31-36, 2014
[34] Tipili, L.G., and Ilyasu, M.S., "Evaluating the Impact of Risk Factors on Construction Projects cost in Nigeria”, The International Journal of Engineering and Science, Volume 3, pp. 10-15, 2014.

[35] El-Sayegh, S.M., and Mansour, M.H., "Risk Assessment and Allocation in Highway Construction Projects in the UAE", Journal of Management in Engineering, Volume 31, No. 6, pp. 04015004, 2015. 